\title{
Cultivation of Rice (Oryza sativa), Corn (Zea mays) and Soybean (Glycine max) Based on Land Suitability
}

\author{
Suntoro SUNTORO*1, Mujiyo MUJ IYO', Hery WIDIJ ANTO', Ganjar HERDIANSYAH' ${ }^{1}$ \\ * Corresponding author \\ ${ }^{1}$ Universitas Sebelas Maret, Faculty of Agriculture, Study Program of Soil Science, Surakarta, Center J ava, INDONESIA \\ E-mail: suntoro_uns@yahoo.co.id \\ DOI: $10.24193 / \mathrm{J} S S P .2020 .1 .02$ \\ https:// doi.org/ 10.24193/J SSP.2020.1.02
}

Ke y w o r d s: cultivations crops, GIS, land evaluation, land management, suitability

\begin{abstract}
A B S T R A C T
Agriculture is the most dominant sector in Magetan district, as indicated by the extent of wetland $\left(282.5 \mathrm{~km}^{2}\right)$ and dryland $\left(406.35 \mathrm{~km}^{2}\right)$ areas. Therefore, planning for agricultural crops development, specifically rice, corn and soybean, must match levels of land suitability. This research aims to evaluate land suitability for rice (Oryza sativa), corn (Zea mays) and soybean (Glycine max) as a basis for food crop cultivation. The research is represented by a field study in the Magetan district of East J ava, consisting of four action stages: (1) formulation of land units; (2) designation of observation points for the stratified proportional sampling of each land unit; (3) field survey; and (4) laboratory analysis. Land evaluation was made in accordance with: Land Evaluation for Rainfed Agriculture Guidelines. Results show that land suitability for rice is classified into the following categories: $37.2 \%$ highly suitable (S1), $58.0 \%$ as moderately suitable (S2) with soil depth and organic carbon soil content as limiting factors, and $4.8 \%$ as marginally suitable (S3), with altitude and low organic carbon as limiting factors. Organic fertilizer from livestock can be applied to maintain and increase soil fertility. Land suitability for corn is classified as highly suitable (S1) - $28.5 \%$, moderately suitable (S2) - $20.0 \%$, with coarse materials and rocky outcrops as limiting factors, and marginally suitable (S3) - 51.5\%, with drainage, coarse materials, and surface rocks as limiting factors. For soybean, land is classified as highly suitable (S1) - 24.3\%, moderately suitable (S2) - 20.4\%, with coarse materials, $\mathrm{pH}$, soil depth, surface rocks, and rocky outcrops as limiting factors, and marginally suitable (S3) - 55.2\%, with drainage, coarse materials, soil depth, surface rocks, and rocky outcrops as limiting factors. Corn and soybean can be cultivated on wetlands in the third planting season with a duration of 3 months. Rice, corn, or soybean crops can be grown on rainfed land using multiple cropping, or agroforestry systems between perennial crops.
\end{abstract}

\section{INTRODUCTION}

To meet the national demand for food over the past five years, the Indonesian government has implemented a Special Effort Program for Rice, Corn, and Soybean (Ministry of Agriculture, 2015). Low food production is the result of land use that does not match its carrying capacity. Land use that exceeds its carrying capacity is not only unproductive, but also leads to land degradation (Herawati et al., 2018). The main problems in agricultural cultivation development are related to water and low levels of soil fertility. In order to develop sustainable farming systems, the focus must be directed to hydrological conditions and local soil fertility. Mapping of soil nutrients can act as a basis for soil fertility management and particularly for determining appropriate doses of fertilizer (J ulianto, 2019). For this reason, planning for the development of agricultural commodities, especially rice, corn, and soybean, must match levels of land suitability.

The goal of land evaluation is to ensure optimal land utilization in accordance with the level of 
land suitability for a particular commodity. Land suitability assessments are based on land quality and land use requirements including plant growth, environmental and management requirements (Wahyunto et al., 2016). Therefore, it is necessary to establish land units based on land quality and the factors that most affect land use. Every region or area of land has its own allocation of use, in accordance with its particular qualities, and other traits, so that it can be utilized optimally and have a high efficiency level. Similarly, the potential of every region is different. In order to recognize the potential of a particular area, it is necessary to identify the qualities, traits, and character of the land and its environment, so that land units can be established.

The arrangement of land units depends on the evaluation goals and the set of relevant core data, including soil, landform, climate, vegetation, and surface water and/ or groundwater reserves. These land units are used as the basis for evaluating land suitability for cultivating rice, corn, and soybean crops. Land suitability describes the level of compatibility of land units for these three selected crops. Evaluation of land suitability means choosing land that is suitable for the crops to be cultivated by interpreting the map of land units with the suitability requirements for each crop and implementing the necessary management steps. In the field of agriculture, land maps are used as the primary basis for evaluating land suitability for various crops that are to be cultivated (Purbaa et al., 2017).

Evaluation of land suitability is a process of assessing land performance when it is used for crop cultivation (FAO, 1976). The main criteria used to evaluate land suitability for crops include land slope, soil depth, soil texture, soil structure, soil drainage, salinity, soil acidity, water supply, soil fertility and environmental factors (FAO, 1976; Pingping and Kurt, 2004). The level of soil fertility, which is indicated by the retention of soil nutrients, is important for determining crop production (J ulianto et al., 2017). The separation of different soil characteristics into land units is essential for evaluating and analysing the potential/suitability of land for a particular type of land utilization. The classes of land suitability are designated as suitable to indicate the level of suitability (S1, S2, S3) and not suitable (N) (Sitorus, 2004). The results of land evaluation provide input for planners and users in developing agricultural land, especially for managing crops in a sustainable manner.

\section{THEORY AND METHODOLOGY}

This research aims to evaluate land suitability for rice (Oryza sativa), corn (Zea mays) and soybean (Glycine max) crops as a basis for food crop cultivation in Magetan area. The research is a field study in the Magetan district of East Java province, Indonesia, consisting of four stages: (1) formulation of land units by overlapping soil maps, topography maps, land use maps, and geographical maps of Magetan district; (2) designation of observation points for stratified proportional sampling of each land unit; (3) field survey to observe the physical and chemical properties of each observation point; and (4) laboratory analysis. The data were compiled in a data-based system that was integrated with other data such as climate data. The stage of compiling a land suitability map for rice, corn, and soybean commodities used a scale of 1:50,000. Land fertility levels were assessed based on soil samples collected from each land unit and also based on observations of soil/land characteristics, which could be used to evaluate land suitability for rice, corn, and soybean commodities.

The laboratory analysis of soil properties included soil $\mathrm{pH}(\mathrm{pH}$ meter and soil to water ratio of 1:2.5), organic $\mathrm{C}$ (Walkley and Black method), total $\mathrm{N}$ in soil (Kjeldahl method), total $\mathrm{P}$ ( $\mathrm{HCl}$ extract method), available P (Bray 2 method), K exchanged (ammonium acetate extract), Ca exchanged (ammonium acetate extract), Mg exchanged (ammonium acetate extract), soil salinity, soil permeability, Cation Exchange Capacity (CEC) (ammonium acetate extract), carried out in the Soil Science Laboratory in the Faculty of Agriculture at Universitas Sebelas Maret.

Activities for evaluating land suitability were carried out for rice, corn, and soybean. For land suitability evaluation it was used a system of matching the land qualities or characteristics with the land use requirements, including growing requirements for rice, corn, and soybean crops, as well as environmental and management requirements, using a framework of land evaluation that refers to Guidelines Land Evaluation for Rainfed Agriculture (FAO, 1983).

The classes of land suitability are assigned symbols, namely S1, S2, S3, and $\mathrm{N}$ to indicate the specific level of suitability. The format and layout of land suitability map with a scale of 1:50,000 uses the geographical maps of Indonesia with a scale of 1:50,000 from the Geospatial Information Agency.

The Land Unit Map and Sample Collection Locations in Magetan District, East J ava, Indonesia are presented in Figure 1.

\section{RESULTS AND DISCUSSION}

\subsection{Physical land conditions in the research area}

The district of Magetan covers an area of $668.84 \mathrm{~km}^{2}$, with bumpy and hilly topographic conditions due to the location, which is directly adjacent to Mount Lawu. The altitude of Magetan district is between 60 and 1,660 meters above sea level, with the majority of the area (66.7\%) at an altitude of 
100-150 meters. The soil type in the research area is dominated by Regosol, brown Mediterran, Grumosol, an association of Mediterran and Grumosol, Alluvial, and Litosol. Agriculture is the most dominant economic sector in the district of Magetan, indicated by the 282.5 $\mathrm{km}^{2}$ of wetland and $406.35 \mathrm{~km}^{2}$ of dryland. Due to the non-uniform geographic conditions, the climate conditions largely vary, from an average air temperature of $22-26^{\circ} \mathrm{C}$ in lowland areas to $16-20^{\circ} \mathrm{C}$ in highland areas. Annual rainfall is in the range of 1,300-1,600 $\mathrm{mm}$ in lowland areas and 2,500-3,000 $\mathrm{mm}$ in highland areas. In 2016, the highest monthly rainfall was recorded in February, with $557 \mathrm{~mm}$ and 29 rain days. Average monthly relative humidity ranges between 77 and 89\%, with the highest value in February 2016 (BPS East J ava, 2017).

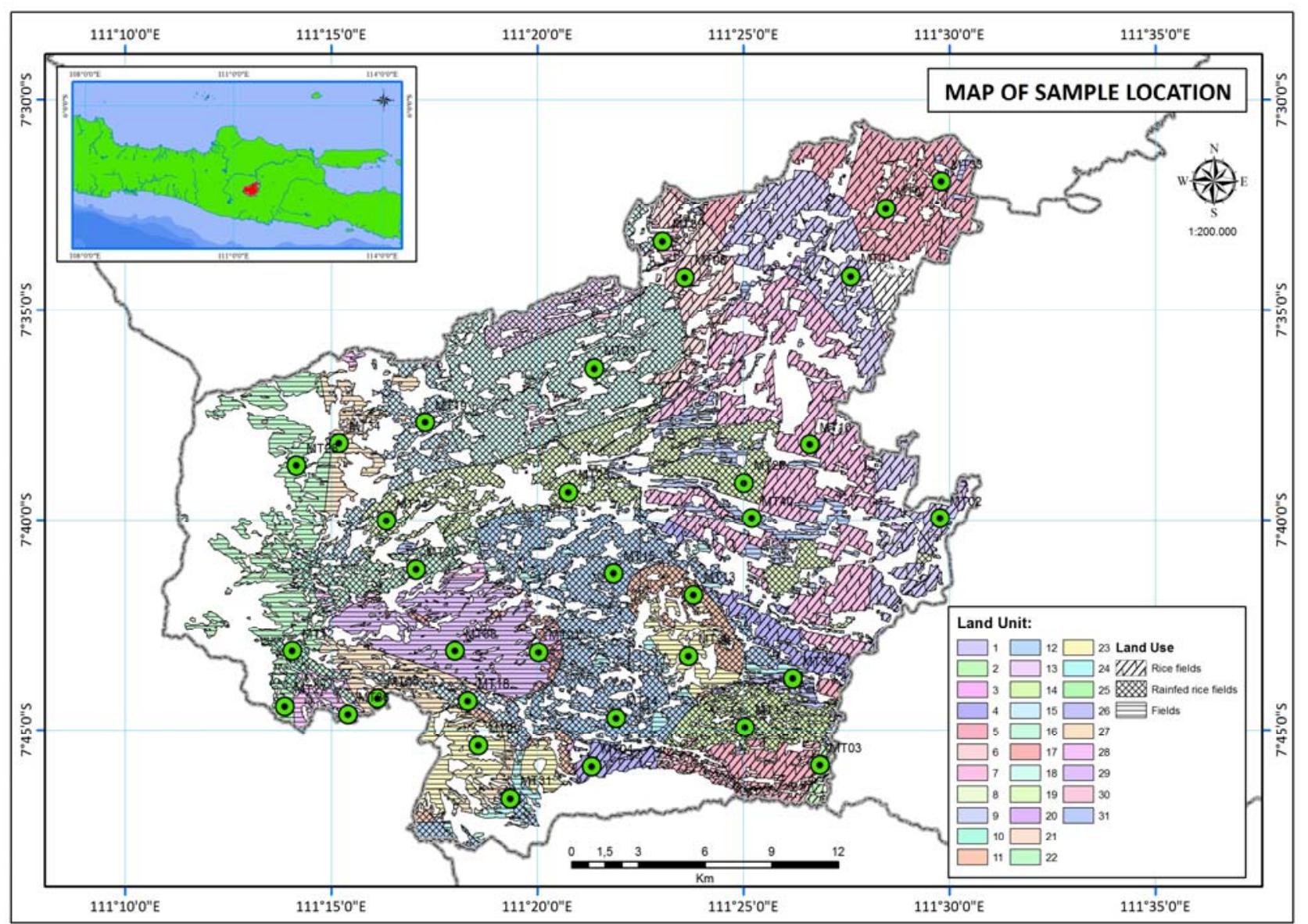

Fig. 1. Map of Sample Location. Magetan District of East J ava Province.

\subsection{Land suitability for rice crops}

Based on the results of land maps overlapping in the district of Magetan (visual Earth maps and topography maps), the research area was divided into 31 land units. Land suitability assessment for rice was carried out on technical irrigation rice field, semitechnical irrigation and rainfed rice fields covering land units 1 to 19. Land suitability for rice crops in the Magetan district ranges from highly suitable (S1) to marginally suitable (S3). Approximately $37.2 \%$ of the area (11,428.0 ha) can be classified as S1 for growing rice. There is not much input for improving or upgrading this land (Fig. 2, Table 1). The majority of land in Magetan district can be classified as S2, with a total area of $17,827.0$ ha $(58.0 \%)$, spatially covering almost entirely the Magetan district. The main limiting factors in class S2 are caused by characteristics of soil depth, soil solum (in the sub-class S2rc), rocks, or coarse materials, with a few locations limited by chemical characteristics such as soil $\mathrm{pH}$ and organic $\mathrm{C}$ soil content. Efforts to improve or upgrade this land can be made by adding organic materials. Land improvement is not an absolute value, but if measures are taken, it will lead to better productivity. Without improvements, this land will still be able to produce rice crops.

The rest of the land (4.8\%) or an area of 1,478.4 ha, can be classified as S3. The distribution of this land is mainly in the southeast part of Magetan district and a small area in the west, specifically on the slopes of Mount Lawu. The dominant limiting factors are altitude, which induces lower temperature, and low content of organic materials or organic C, falling into the sub-class S3wa/nr. In areas where the limiting factors are temperature or altitude, no improvements 
can be made except with the use of high technology, which will not necessarily be profitable from an economic point of view.

In areas where the limiting factor is low organic $\mathrm{C}$ content, improvements to the land can be made by adding organic materials such as manure or other materials to increase the organic $\mathrm{C}$ content in the soil. Cattle manure has a nutrient content that is complete and relatively available for the plants. This is due to the fact that the food material has undergone a perfect transformation in a short period of time (Suntoro et al., 2018).

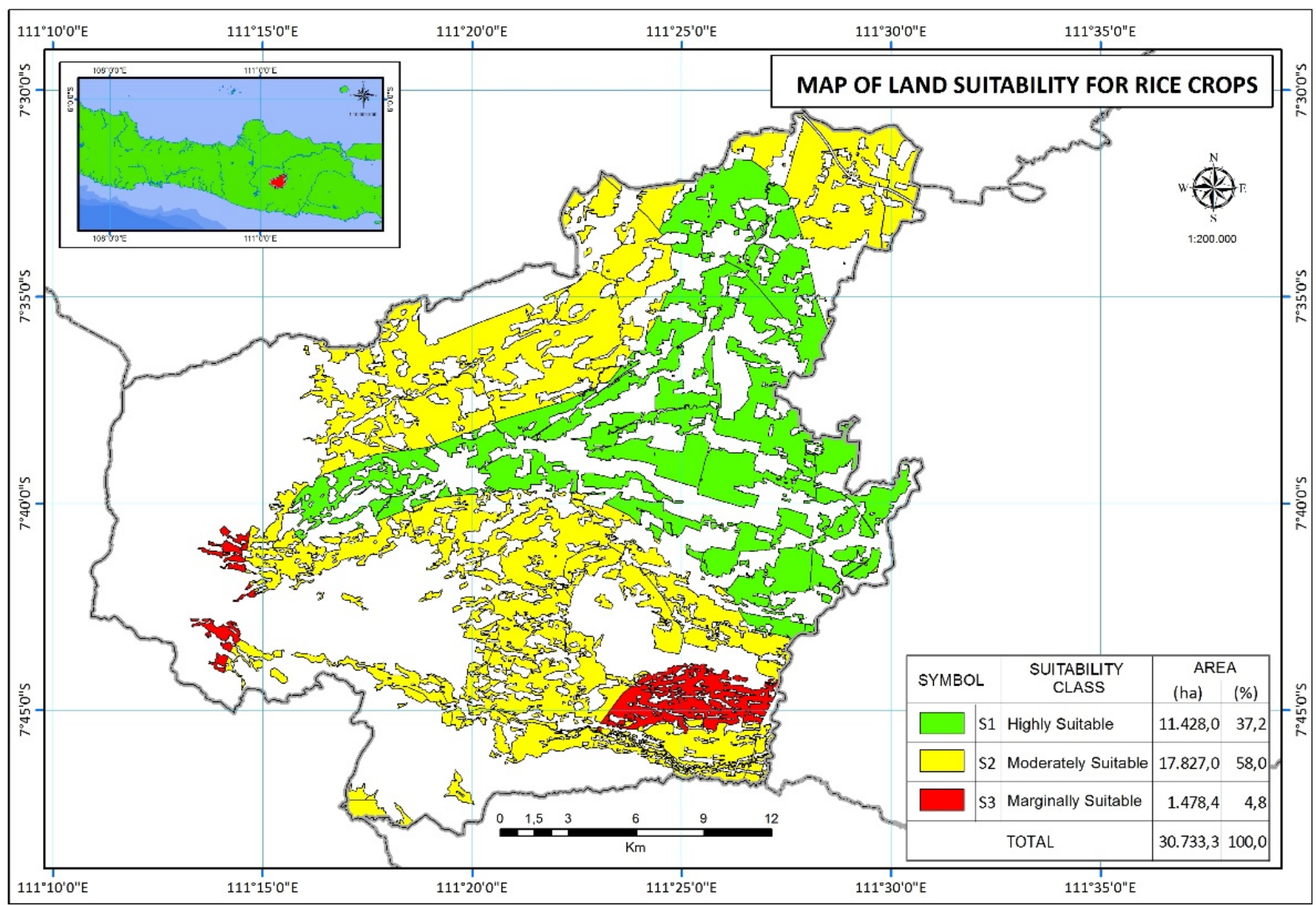

Fig. 2. Map of land suitability for rice crops.

Table 1. Land suitability sub-classes and area for rice, corn, and soybean crops.

\begin{tabular}{|c|c|c|c|c|c|}
\hline Class & $\begin{array}{c}\text { Suitability } \\
\text { sub-class }\end{array}$ & $\begin{array}{c}\text { Area } \\
\text { (ha) }\end{array}$ & $\begin{array}{c}\text { Share } \\
(\%)\end{array}$ & Limiting factors & Land unit \\
\hline \multicolumn{6}{|c|}{ A. Suitability class for rice crops } \\
\hline S1 & S1 & 11,428 & 37.2 & - & $1,7,17$ \\
\hline $\mathrm{S} 2$ & S2rc & 17,287 & 58.0 & Soil Solum, Carbon Organic & $2,3,4,5,6,8,9,11,12,13,15,16,18,19$ \\
\hline S3 & S3wr, rc, nr & 1,478 & 4.8 & $\begin{array}{l}\text { Rock materials, nutrient retention } \\
\text { (C-organic) }\end{array}$ & 10,14 \\
\hline \multicolumn{6}{|c|}{ B. Suitability class for corn crops } \\
\hline S1 & $\mathrm{S} 1$ & 12,073 & 28.5 & - & $1,4,7,27,31$ \\
\hline S2 & S2rc, oa & $8,470.5$ & 20.0 & $\begin{array}{l}\text { Rock materials, rock outcrop, } \\
\text { solum }\end{array}$ & $3,8,9,10,11,13,16,17,18,22$ \\
\hline S3 & S3rc, oa & $21,871.7$ & 51.5 & $\begin{array}{l}\text { Rock materials, rock outcrop, } \\
\text { drainage }\end{array}$ & $2,5,6,12,14,15,19,23,26,29,30$ \\
\hline \multicolumn{6}{|c|}{ C. Suitability class for soybean crops } \\
\hline S1 & S1 & $10,315.9$ & 24.3 & - & $1,4,7,31$ \\
\hline $\mathrm{S} 2$ & S2rc & $8,647.7$ & 20.4 & Solum, rock outcrop, drainage & $11,16,17,19,24,26,27,28$ \\
\hline S3 & S3wr, rc, oa & $23,411.7$ & 55.2 & $\begin{array}{l}\text { Water, Solum, rock outcrop, } \\
\text { drainage }\end{array}$ & $2,5,6,10,12,14,15,18,22,23,26,29,30$ \\
\hline
\end{tabular}

The addition of organic materials to the soil will cause a rise in the soil's organic material content, soil $\mathrm{pH}$, and total $\mathrm{N}$ in the soil, as well as increasing the availability of macronutrients such as $\mathrm{P}, \mathrm{K}, \mathrm{Ca}$, and $\mathrm{Mg}$, increasing cation exchange capacity (CEC), and improving crop production (Lani et al., 2014). 


\subsection{Land suitability for corn crops}

Based on the results of the field survey and data from the laboratory analysis, it was found that land suitability for corn crops in Magetan district, including irrigated wetland, rainfed wetland, and moorland, can be classified as S1, S2, and S3. An area of 12,073.0 ha (28.5\%) is classified as $\mathrm{S} 1$ for corn crops, while 8,470.5 ha (20.0\%) is classified as S2, with coarse materials and rocky outcrops as the limiting factors, thus falling into the sub-class S2rc.oa. Land suitability as S2 also has the potential to be used for cultivating corn crops. Therefore, the potential for developing corn crop cultivation is still quite good. Land classified as S3 covers a fairly wide area, namely $21,831.7$ ha (51.5\%) (Fig. 3 and Table 1).

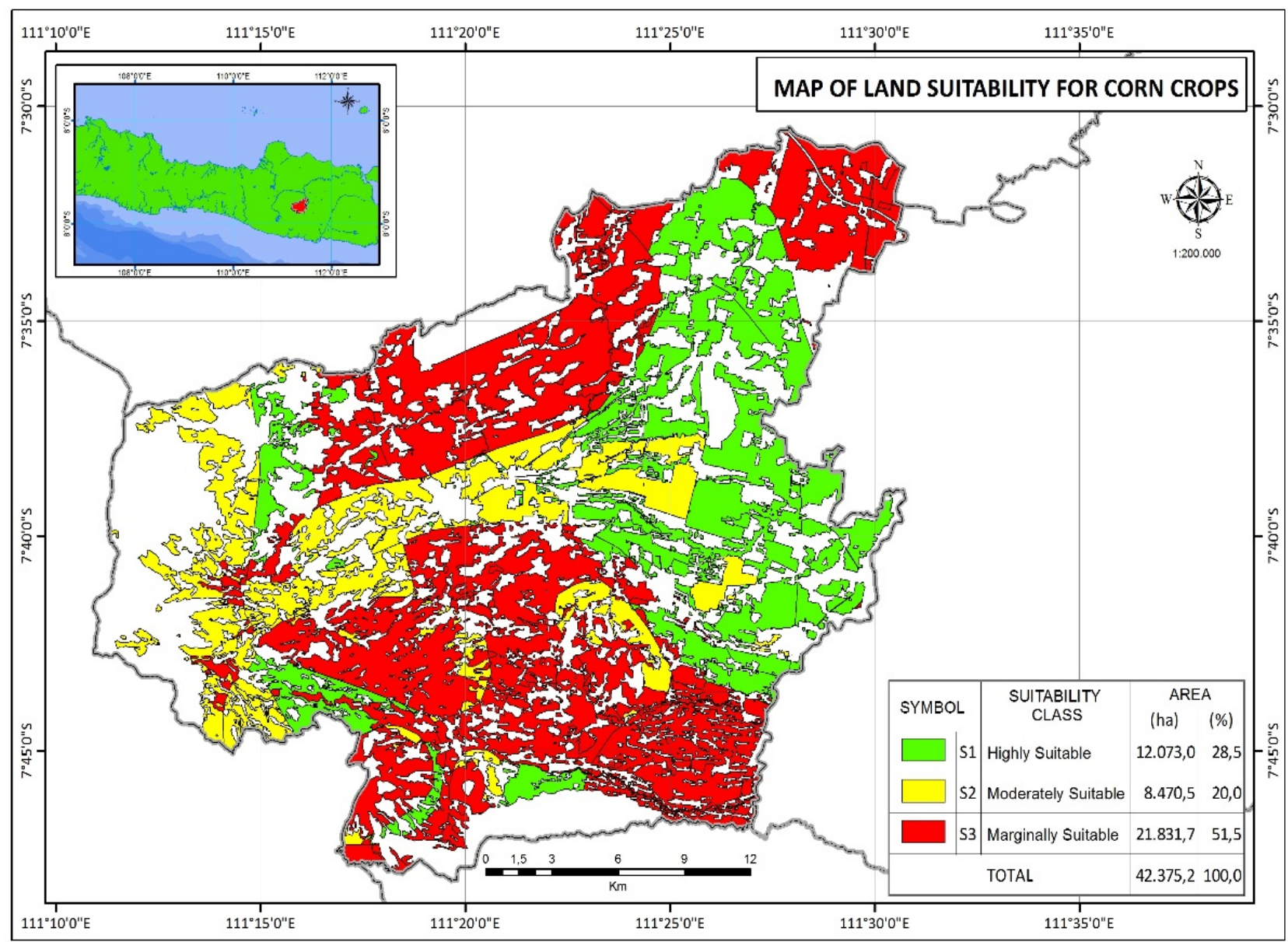

Fig. 2. Map of land suitability for corn crops.

The limiting factors for S3 land for corn crop cultivation are drainage, coarse materials, and surface rocks, thus falling into the sub-class S3rc.oa.

Drainage obstruction is due to the fact that the soil type on most of the wetland is Grumosol and Mediteran or a Mediteran-Grumosol association, which is characterized by slow water release due to the high clay content.

The solution for improving the class of land suitability from S3 to S2 for corn cultivation is to ensure better drainage by tilling the land and creating drainage channels for every row of crops. Development of corn cultivation in highland areas can use a pattern of agroforestry, or multiple cropping, in which corn plants are planted alongside other crops such as coffee, or forest plants, namely pine trees. However, this pattern of agroforestry can only be used at the start of the growth of the perennial crops (Maruto et al., 2017).

\subsection{Land suitability for soybean crops}

Based on the results of the field survey and data from the laboratory analysis, it was found that land suitability for soybean crops in Magetan district, including irrigated wetland, rainfed wetland, and moorland, can be classified as S1, S2, and S3.

Land that can be classified as S1 for soybean crops extends over $24.3 \%$ or $10,315.9$ ha, while S2 land for soybean crops covers 8,647.7 ha (20.4\%) (Fig. 4 and Table 1). Land classified as S2 also still has the potential to be used for cultivating soybean crops. Therefore, the potential for developing soybean crop cultivation can still be improved. The limiting factors of land classified as S2 are coarse materials, $\mathrm{pH}$, soil depth, surface rocks, and rocky outcrops (in sub-class S2rc). Meanwhile, land classified as S3 covers a fairly wide area, namely $23,411.7$ ha (55.2\%). The limiting factors of S3 land for 
soybean cultivation are drainage, coarse materials, soil depth, surface rocks, and rock outcrops, thus falling into the sub-class S3rc. In order to maintain and improve the level of soil fertility, the application of organic materials is needed. In addition to applying manure, the use of Mycorrhiza has a strong impact on increasing nutrient availability and improving soybean crop production (Samanhudi et al., 2018).

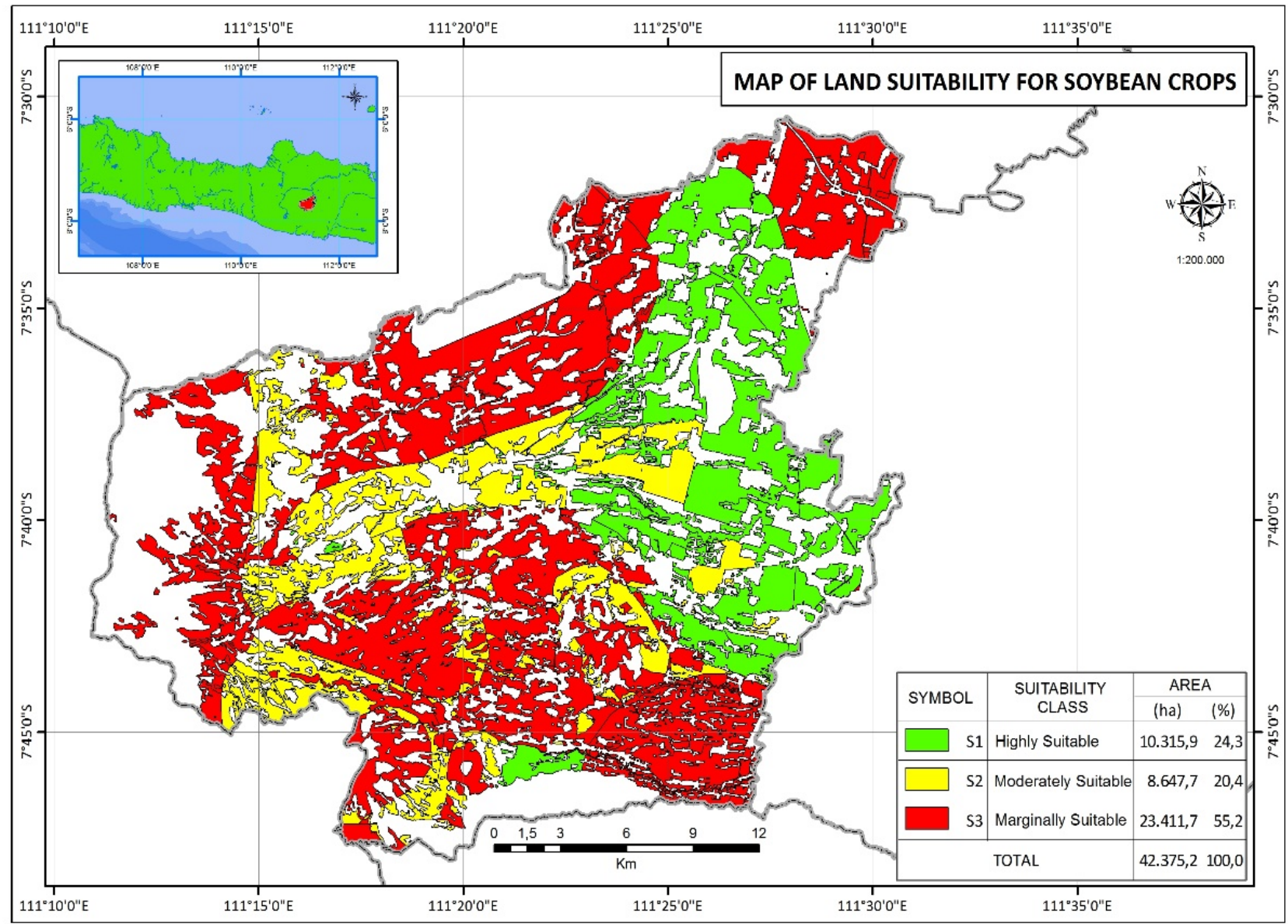

Fig. 4. Map of Land Suitability for Soybean Crops.

\subsection{Land management and cropping patterns}

Based on the evaluation of land suitability, it was found that land in Magetan district ranges from S3 to S1 for rice cultivation. The area of wetland in Magetan is of approximately $282.5 \mathrm{~km}^{2}$ and the rest is rainfed land. Wetland areas can be planted for 3 growing seasons. The research location belongs to the C2 climate type based on Oldeman classification, this wetland utilizes irrigation channels and pump wells to grow rice. Rice plants need 110 days to be harvested using superior varieties. On some rainfed land, at an altitude between 200 and $900 \mathrm{~m}$, rice can also be grown for 3 planting seasons, whilst the 3rd season (dry season) makes use of pump wells. Rice is generally planted as a monoculture, three times a year. This cultivation method is still quite safe from pests because of the reasonably long gap after the first rice planting (around 1 month). On rainfed land, a multiple cropping system is used.

Most of the soil area in the research region has a relatively low content of organic material, which in some land units is a limiting factor. The use of organic material is the main key to the successful cultivation of rice, corn, and soybean crops. The research results of Suntoro et al. (2018) show that the application of compost is able to provide the necessary nutrition for crop growth, and this also has the potential to offer a long-term benefit for soil health and sustainable agricultural cultivation.

In crop cultivation on dryland, the condition of soil moisture plays an important role. Dry stress inhibits the increase of soybean plant height and leaf area. When stress becomes worse, longer, and more frequent, the effect of this inhibition becomes more significant (Dong et al., 2019).

In order to reduce evaporation and preserve soil moisture on dry land, it is beneficial to use straw mulch. The use of organic mulch will increase the efficiency of water use, with an increase of 25-47\% if compared with empty land. Straw mulch has the ability to modify the hydro-thermal regime of the soil in soybean cultivation on rainfed land. The effect of mulch is to produce a significant increase in plant biomass, 
plant height, leaf chlorophyll, root nodules, bean yield, and efficiency of water use by soybean plants on rainfed land if compared with empty land (Kader et al., 2019).

The use of rice waste, other than straw, as mulch, through a process of pyrolysis of rice husk biochar, has the ability to improve the efficiency of fertilization. The application of biochar itself, at an optimal level or in combination with anorganic fertilizer, can increase photosynthesis, improve plant growth and produce a more satisfactory bean yield (Qian et al., 2019).

Soybean crops are extremely useful for maintaining soil fertility by including them in crop rotation (rice - rice - soybean), or multiple cropping of corn and soybean. Soybean is a leguminuous plant that is suitable for use in multiple cropping as a strategy for managing soil fertility. This corn-soybean system is able to suppress the use of nitrogen fertilizer (diammonium phosphate). However, attention needs to be given to the regulation of plant distance in order to prevent competition between the two crops. The result of such competition may lead to an obstruction of lignin biosynthesis and a lack of photosynthates (soluble sugars) for the biosynthesis of cell walls, causing a reduction in strength (Wei-guo et al., 2019).

Soybean plants are often included in crop rotation after the second planting season. Even though soybean belongs to the family of Leguminosae, it still requires the application of fertilizer. Nishida (2016) reports that crop rotation between irrigated paddy fields (Oryza sativa) and soybean (Glycinemax) induces a reduction in soil nitrogen $(\mathrm{N})$ fertility, which is shown by the availability of $\mathrm{N}$ in the soil. Total soil carbon also tends to decline with the increase in frequency of wetland use. The physical properties of soil are affected by upland rice rotation. Organic materials contained in the soil are decomposed in upland rice rotation, while soil density increases with a decline in soil porosity. The key to control soil nitrogen in the cultivation of rice is by adding organic materials to the soil and applying nitrogen fertilizer at regular intervals (Nishida, 2016). Soybean and corn plants in highland areas with bumpy topography can be cultivated using a system of agroforestry. This agroforestry system not only helps with soil conservation in the threat of landslide erosion but also increases farmers' income (Priyono et al., 2018).

\section{CONCLUSIONS}

The results of the research show:

Land suitability for rice crops: S1 - 37.2\%; S2 $58.0 \%$ with soil depth and organic $\mathrm{C}$ content as limiting factors, and S3 - 4.8\%, with altitude and low organic C content as limiting factors. Land management endeavours should be directed towards the addition of organic materials (manure and compost). Technical rice fields can be used for three planting seasons, and in the third planting season, corn or soybean crops can be grown.

Land suitability for corn crops: S1 - 28.5\%, S2 $20.0 \%$, with coarse materials and rocky outcrops as limiting factors (S2rc.oa), and S3 - 51.5\%, with drainage, coarse materials, and surface rocks as limiting factors. In the rainy season, flooding can be avoided by constructing drainage channels.

Land suitability for soybean crops: S1 - only $24.3 \%$, S2 - 20.4\%, with coarse materials, $\mathrm{pH}$, soil depth, surface rocks, and rocky outcrops as limiting factors; S3 - 55.2\%, with drainage, coarse materials, soil depth, surface rocks, and rocky outcrops as limiting factors. In the rainy season, flooding can be avoided by constructing drainage channels.

Cultivation of corn or soybean crops on wetlands can be done in the third planting season (dry season), and water can be supplied by pumping groundwater. Cultivation on rainfed land can be implemented using a system of multiple cropping of rice, corn, and soybean plants, or using a system of agroforestry with perennial crops.

\section{REFERENCES}

BPS (2017), Propinsi Jawa Timur dalam Angka tahun 2017. Surabaya. East J ava.

Dong S,. J iang Y., Dong Y., Wang L., Wang W., Ma Z., Yan C., Ma C., Liu L. (2019), A Study on Soybean Responses to Drought Stress and Rehydration. Saudi J ournal of Biological Sciences, 26(8), 2006-2017. DOI: https:// doi.org/ 10.1016/j.sjbs.2019.08.005

FAO (1983), Guidelines Land Evaluation for Rainfed Agriculture. Soil Resources Management and Conservation Service Land and Water Development Division. FAO Soil Bulletin No. 52. FAO-UNO, Rome.

FAO (1989), Community Forestry, Participatory Assessment, Montoring and Evaluation. FAO: Rome.

FAO (1976), A Framework for Land Evaluation, Soil Bulletin 32. FAO : Rome.

Herawati A., Suntoro Widijanto, H., Sutopo N. R., Mujiyo (2018), Soil degradation level under particular annual rainfall at Jenawi DistrictKaranganyar, Indonesia. IOP Conference Series: Earth and Environmental Science 129(1). DOI: 10.1088/17551315/ 129/ 1/ 012010.

Julianto E. A., Suntoro W. A., Dewi W. S., Partoyo (2018), Graphical approach to assess the soil fertility evaluation model validity for rice (case study: Southern area of Merapi Mountain, Indonesia). IOP Conference Series: Earth and Environmental Science 129(1). DOI: 10.1088/ 1755-1315/ 129/ 1/ 012012.

Julianto E. A., Suntoro W. A., Dewi W. S., Partoyo (2019), Mapping Indigenous Nutrient Status of Post-Eruption Soil to Support the Fertilization of Rice (Oryza sativa) in the Southern Area of Merapi 
Mountain, Indonesia. Journal of Settlements and Spatial Planning 10(1), 29-38. DOI: 10.24193/J SSP .2019.1.03.

Kader M. A., Nakamura K., Senge M., Mojid M. A., Kawashima S. (2019), Soil Hydro-Thermal Regimes And Water Use Efficiency Of Rain-Fed Soybean (Glycine max) As Affected By Organic Mulches. Agricultural Water Management 223. DOI: https:// doi.org/ 10.1016/j.agwat.2019.105707.

Ilagan L. A., Tablizo R. P., Barba Jr. R. B., Marquez N. A. (2014), (2014), Soil Fertility Evaluation For Rice Production In Catanduanes Province, Philippines. International Journal of Scientific \& Technology Research 3(12). URL: http:// www.ijstr.org/ final-print/ dec2014/ Soil-FertilityEvaluation-For-Rice-Production-In-Catanduanes-

Province-Philippines.pdf

Maruto Suntoro W, A., Sutrisno Joko, Priya Darsini Rosita (2017), Net farm income as reflection of critical land evaluation in welang watershed, Indonesia. Bulgarian Journal of Agricultural Scienœe, 23 (5), 826833. URL: https:/ / www.agrojournal.org/ 23/ 05-21.pdf Ministry of Agriculture (2015), Peraturan Menteri Pertanjan Republik Indonesia Nomor 03 /Permentan/OT.140/2/2015 Tentang Pedoman Upaya Khusus (UPSUS) Peningkatan Produksi Padi, Jagung Dan Kedelai Melalui Program Perbaikan Jaringan Irigasi Dan Sarana Pendukungnya Tahun Anggaran 2015. J akarta.

Nishida, M. (2016), Decline in Fertility of Paddy Soils Induced by Paddy Rice and Upland Soybean Rotation, and Measures against the Decline. Japan Agricultural Research Quarterly 50 (2), 87-94. URL: https:// www.jircas.go.jp/ sites/default/ files/publication/jarq/ 5 0-02-02_087-094_NISHIDA_1.pdf

Jiang P., Thelen K. T. (2004), Effect of Soil and Topographic Properties on Crop Yield in a NorthCentral Corn-Soybean Cropping System. Agronomy J ournal 96(1), 252-258. DOI: https:// doi.org/ 10.2134/ agronj2004.0252

Priyono Rahayu Minardi S., Suntoro (2017), Morphology of Landslide prone of agriculture area in the sub watershed Samin upstream based on landslide type used for considerations of early mitigation model. International Journal of Mechanical Engineering and Technology 9(7), 462-475. URL: http://www.iaeme. com/MasterAdmin/J ournal_uploads/ IJ MET/VOLUM E_9_ISSUE_7/IJ MET_09_07_050.pdf

Zhu Q., Kong L., Shan Y., Yao X., Zhang H., Xie F., AO X. (2019), Effect of Biochar on Grain Yield and Leaf Photosynthetic Physiology of Soybean Cultivars with Different Phosphorus Efficiencies. Journal of Integrative Agriculture, 18(10), 2242-2254. DOI: https:// doi.org/ 10.1016/ S2095-3119(19)62563-3
Soil Research Center (1983), Terms of Refference Klasifikasi Kesesuaian Lahan. Proyek Penelitian Pertanian Menunjang Transmigrasi (P3MT). Soil Research Center. Bogor.

Soil Research Center (1983), Term of Reference Klasifikasi Kesesuaian Lahan. Soil Research Center. Bogor. Samanhudi Pujiasmanto B., Yunus A., Suntoro S., Widijanto H., Prabowo S. M. (2017), The effect of manure and mycorrhiza application to the soil microbes biodiversity in terms of increasing soybean yield in marginal land in Indonesia. Bulgarian J ournal of Agricultural Science 23(6), 994-1003. URL: https:/ / www.agrojournal.org/23/06-16.pdf

Sitorus S. R. P. (2004), Evaluasi Sumberdaya Lahan. Penerbit Tarsito. Bandung.

Suntoro S., Widijanto H., Suryono Syamsiyah J., Afi nda D. W., Dimasyuri N. R., Triyas V. (2018), Effect of cow manure and dolomite on nutrient uptake and growth of corn (Zea mays). Bulgarian Journal of Agricultural Science, 24(6), 1020- 1026. URL: http:/ / www.agrojournal.org/24/ 06-12.pdf

Purbaa T., Harahap E. M., Hanum C., Rahmawaty (2017), Land Suitability Evaluation For Paddy, Corn and Soybean in Binangalom Watershed Toba Samosir District North Sumatra. International Journal of Sciences: Basic and Applied Research (IJ SBAR) 33(1), 131-144. URL: http:// repository. usu.ac.id/ bitstream/ handle/ 123456789/ 69523/ Full text.pdf?sequence $=1$ \&isAllowed $=\mathrm{y}$

Wahyunto Hikmatullah, E., Suryani C., Tafakresnanto S., Ritung A., Mulyani Sukarman K., Nugroho Y., Sulaeman Y., Apriyana Suciantini A., Pramudia Suparto R. E., Subandiono T., Sutriadi D. Nursyamsi (2016), Petunjuk Teknis Pedoman Penilaian Kesesuaian Lahan untuk Komoditas Pertanian Strategis Tingkat Semi Detail Skala 1:50.000. Balai Besar Penelitian dan Pengembangan Sumberdaya Lahan Pertanian, Badan Penelitian dan Pengembangan Pertanian, Bogor. 37 hal. URL: $\quad$ https:// www.google.com/ url?sa=t\&rct=j\&q= \&esrc=s\&source $=$ web\&cd $=\& v e d=2 a h U K E w j l k v P 0 \_q v q$ AhWGs4sKHdOQBNYQFjAAegQIAxAB\&url=http\%3A \%2F\%2Fbbsdlp.litbang.pertanian.go.id\%2Find\%2Finde x.php\%2Fpublikasi-3\%2Fpetunjuk-

teknis\%3Fdownload\%3D22\%3Apedoman-penilaiankesesuaian-lahan-untuk-komoditas-pertanianstrategis\&usg=AOvVaw0xpS_YTSKZldOWR0kGP95Q Liu W., Wen B., Zhou T., Wang L., Gao Y., Li S., Qin S., Liu J., Yang W. (2019), iTRAQ Protein Profile Analysis Of Soybean Stems Reveals New Aspects Critical For Lodging In Intercropping Systems. J ournal of Integrative Agriculture 18(9), 2029-2040. DOI: https:// doi.org/ 10.1016/ S2095-3119(18)62123-9 